\title{
Ethnomathematics in Traditional Games Java Jiting-Jitingan: An Approach to Improve the Quality of Mathematics Learning
}

\author{
E F Ningsih"1, S Widyawati², M Mahmudi ${ }^{3}$, W Kusumaningtyas ${ }^{4}$ \\ Mathematics of Study Programmer, Institute for Islamic Study Ma'arif NU (IAIMNU) Metro, \\ Indonesia ${ }^{1,2,3,4}$ \\ \{ekamatika@gmail.com¹, Santiwindyawati24@gmail.com², moedynatha@gmail.com³ \\ wahyutyas03@gmail.com $\left.{ }^{4}\right\}$
}

\begin{abstract}
Mathematics is a form of abstraction from problems that occur in life so that not infrequently many students who have difficulty in learning mathematics. No wonder if the current math is still a subject that is not liked by students. This is where the need for reformative learning of mathematics with an ethnomathematics approach based on Indonesian culture. This study explore the traditional game culture of Java and relate it to the learning of mathematics. This research includes descriptive qualitative research. Subjects in this study are children of Javanese who ever played "jiting-jitingan". Javanese tribes spread throughout most of the region. This study uses the subject of tribal children who live in Metro Lampung. From the information obtained further, the researchers connect with mathematics learning on the subject line and gradient. From the results of data analysis conducted by using descriptive analysis and discussion as follows: 1) The line equation can mathematics learning with ethnomathematics approach based on a traditional game is one form of an innovative approach to learning. 2) Integrating game and culture mathematics into activities that need to be done. Mathematical materials that can be taught through this game are addition, lines, and gradient.
\end{abstract}

Keywords: Ethnomathematics, games, gradient, lines. 


\section{Introduction}

Indonesia is a country with a high level of cultural diversity. Cultural diversity makes a country attractive to its diversity. Cultural diversity should make Indonesia rich and able to stand in line with other developed countries. According to the Minister of Home Affairs Regulation, "Conservation is an effort to preserve and maintain the social and cultural customs of the people concerned, especially the ethical, moral, and values that are at the core of customs, customs in society and customary institutions its existence is maintained and continues". Thus, efforts to preserve the nation's culture. Besides being famous for its cultural diversity, Indonesia is also famous for its religious diversity. However, the current cultural values have begun to be abandoned by the community, especially in the younger generation. So not infrequently, many young people who do not understand the culture they have.

Learners are individuals who are developing toward maturity and independence. To achieve maturity and independence of course there needs to be guided through education. School education needs to instill cultural and religious values. The current educational paradigm needs a balance between intellectual, moral and cultural values. Thus, the need for a learning innovation that integrates culture with subjects. Mathematics is one of the subjects given in every level of education[1]. Mathematics is a form of abstraction from problems that occur in life so that not infrequently many students who have difficulty in learning mathematics[2]. An abstract form, many symbols coupled with less supportive learning students comfortably learn in the classroom exacerbate the process of learning in the classroom. No wonder if the current math is still a subject that is not liked by students. This is where the need for reformative learning of mathematics with an ethnomathematics approach based on Indonesian culture.

The internalization of culture in the learning of mathematics through ethnomathematics can be done. One of the recommended cultures can be identified as traditional culture. The presentation of enjoyable learning with traditional games in addition to helping the learning process can also be an effort to preserve the culture itself. The meaningfulness of learning will create interest so that by itself students will feel interested in learning math. In the tribe of Java, there is a traditional game played by children at playtime. The traditional game is "jitingjitingan". The term "jiting-jitingan" is taken from the Java language because the game is a media stick. In this article will describe the "jiting-jitingan" game and its relation to the learning of mathematics

\section{Theoretical Review}

\section{$2.1 \quad$ Ethnomathematics}

Ethnomathematics is special ways that a particular cultural or community group engages in mathematical activity[3]. According to Borba [4], ethnomathematics can be described as the way in which people from certain cultures use mathematical ideas and concepts to address the quantitative, relational, and spatial aspects of life. According to Ascher [5], ethnomathematics is mathematics that grows and develops in a particular culture. Ethnomathematics is perceived as a lens for viewing and understanding mathematics as a cultural product. Thus, ethnomathematics is an activity to study mathematics in a particular culture. Ethnomathematics is defined as the special ways used by a particular cultural or community group in mathematical activities. 
Mathematics learning activities tend to be formal. Look at mathematical characteristics that are identical with abstract shapes and full of symbols. Formal learning packaging tends to make math difficult to understand. In essence, when learning has significance for learners it will be easy and attract learners to follow the lesson. The habit that has been done by society in the form of culture. Mathematics is also a cultural product of the abstraction of the human mind, as well as problem-solving tools[3]. Traditional cultural linkage with mathematics lessons will make an interesting contribution so that learning does not tend to be formal. Furthermore, according to the theory that when the psychological situation students comfortable, relaxed and not depressed it will be easier for learners to get information from outside. Activities that attract the attention of learners one of them is the form of the game. During this time, learners tend to play modern games such as gadgets. Culture owned should be maintained. Not a few current learners who do not understand the traditional game they have. Traditional games should be preserved because in addition to traditional cultural heritage games emphasize very high social interactions than games in gadgets that tend to teach individual habits. In character formation of course less good. Therefore, there is a need for a breakthrough in mathematical learning that connects traditional game culture. According Shirley needs innovation to improve the ability in reasoning, problemsolving through contextual teaching materials[3]. Indonesia's achievement in the PISA event in 2015 has increased compared to the previous year. This indicates that there has been a change to a better condition. However, the ranking of PISA in the mathematical category is still at the order of 63 out of 70 States. Thus, academics need to develop innovative learning innovation through ethnomathematics. Ki Hajar Dewantara asserted that culture cannot be separated from education, even culture becomes the basis of education. In education, there are two main missions: value transfer and knowledge. Thus, teachers not only transfer knowledge but also must be able to transfer the value of local wisdom in the student environment (Arisetyawan et al 2014). The importance of teachers to instill the value of local wisdom in line with government policies that proclaim character education. But unfortunately, not many teachers who apply culture-based learning.

With the innovation of learning that relates mathematics to the culture, of course, need to be applied in education. The curriculum used should apply mathematics that has a context or relationship to everyday life[4]. Classroom learning should use approaches that encourage more free classroom practice using ethnomathematics. Ethnomathematics helps students get to know the culture so that students can get to know more applicative maths and can successfully master math academically.

Ethnomathematics was created by Ubiratan D'Ambrosio to recognize two mathematical fields of school mathematics and the mathematical practice of a particular cultural group. His research on the concept of the curriculum by integrating ethnomathematics called the Ethnomathematics program. According to Gutiérrez and Irving, the enormous benefit of integrating ethnomathematics in the curriculum is to help students connect their culture with mathematics[6].

\subsection{Culture}

According to Tylor culture is a complex whole, in which there is another science and habits that people get as members of society [7]. The word culture with al-tsaqafah (Arabic) is a form of expression of the deep spirit of a society reflected in the forms of art, literature, religion 
(religion) and morals[8], [9]. Culture is the whole system of ideas, actions, and the results of human ingenuity to create their needs by learning that can all be found in people's lives[10]. Kuntjaraningrat argues that "culture" is derived from the Sansekerta plural form of Buddhi which means mind or intellect, so that according to him culture can be interpreted as the things concerned with reason and mind, there is also the opinion as a development of cultivation that means power of mind or strength of reason [11], [12]. According to Soekanto elements of culture include Equipment and equipment for human life, Living livelihood, Community system, Language, Art, Knowledge system, and The belief system (religion) [13].

\subsection{Islamic Culture in Indonesia}

The traditional game is a hereditary heritage. Traditional games are found by children. In contrast to children of modern times who know gadgets in children of ancient familiar traditional games that tend to be practical, simple and easy to play According to Danandjaja Traditional games are divided into two namely play games with games to compete. Traditional games are usually aimed at children who at this time are very happy to play[14]. Games and children are inseparable. Almost all the time the lives of children are always in play condition. Naturally, a child who grows somewhere will play a traditional game that develops in place. Symptoms Currently the tendency to manifest Islamic culture in the life of the nation is divided into two tendencies namely the formalization of Islamic teachings in all cultural manifestations and the second tendency to stay away from the formalization of Islamic teachings in cultural manifestations. The religion of Islam comes from revelation and has a norm that its existence remains. In contrast to the culture that is the result of the creation of human works so it is possible to change and evolve according to the changing times. However, even though different cultures and religions both have interconnectedness, culture is used as a way to show greatness to religion.

Broadcasting religion by Sunan Kalijaga for example, by building a Demak mosque with a layered roof. The previous culture had a layered belief consisting of Nine stacks (HinduBuddhist concept) while by Sunan Kalijaga the stack was converted into three layers. Cultural values are maintained but there are Islamic teachings inserted in them. The three layers are interpreted as the religious stages of faith and Islam. From the explanation, it is seen that the culture is used as a median to spread the religion of Islam. By integrating the teachings of Islam in the culture will facilitate these teachings to be accepted by society.

There are two tendencies of the development of Islam in Indonesia is the process of arabization and indigenization. Arabization is the process of identifying eastern cultures [15]. This process is based on the notion that Islam originates from the Middle East so that it is necessary to adapt Islam to Islam in the Middle East. Such a process will result in the loss of culture owned by the country itself. On the other hand, there is a tendency of the indigenous process of maintaining the culture by not leaving the teachings of Islam. Adjustment of Islamic teachings is permitted so long as it concerns the cultural and customary sides. Naumn, if it concerns religious norms then the teachings of Islam cling to the provisions of Islam.

The religious dissemination of religion as friendly to the culture as it was done by the guardians in the past made Indonesia as a reference country of Islam. Islamic references nowadays have not gone to Islam in the Middle East because until now there is still a commotion. While in Indonesia, Islam is born and mergers on the culture of the archipelago itself are not on 
the perspective of western and Arab. Then came the term Islam Nusantara. Islamic studies of the archipelago are not just a study of the Islamic region but more importantly its study of Islamic values that have grown in this region.

Islamic archipelago is Islam by way of a cultural approach that is friendly, polite and integrates with the culture [16]. Thus Islamic archipelago is not Islam that uses rigid and hard doctrine. Islamic archipelago is preached and preserved using culture. The Islamic preaching performed by Walisongo reflects the preaching that is tolerant of the local culture. Like the teachings of Sunan Kalijaga. The teaching is able to adapt in introducing Islam. He uses the art of sculpture, wayang, gamelan and sound art as a means of religious preaching.

\subsection{Java}

Java community is a society famous for its polite and refined culture. The people of Java tend not to be frank because of his character who does not want to cause conflict and maintain harmony. In a discussion, Javanese people tend not to like to deny and accept the opinions of others. The people of Java, not only on the island Java but spread and inhabited several islands in Indonesia is included Lampung Province. Metro City is one of the most successful transmigrant cities to date. In 1935, in addition to bringing the population from Java, the Dutch also moved some communities from the colonization village. Javanese society is classified into three groups namely "wong cilik" group consisting of farmers who have low income. The second group is the "priyai" group consisting of employees. A third group is a top-level group of so-called "ningrat" groups. A polite and respectful attitude in the principle of Javanese society can be seen in traditional games, this principle can be seen at the time the children will make a draw before playing, the losing child will respect the winning child in the draw and invite to start the game traditional first.

\section{$2.5 \quad$ Traditional Game}

The traditional game is a traditional game People of an area, this game can be a good tool in developing children's education. One of the main, this game is capably Providing educational elements to children at a cost cheap and satisfactory result. The traditional game is heavily loaded with the moral and cultural values of the supporting community. Besides the game traditional or folk games prioritize the value of his creation as well as a medium of learning. Traditional games inculcate life attitudes and skills such as the value of cooperation, togetherness, discipline, honesty because there are rules that must be met by the players. In traditional games much involves gestures, involving songs or sounds as a medium, involving the playground. Games that involve songs prefer the lyrics of songs that contents invite, instill ethics and morals, or just have fun. Traditional game materials, processes, and functions are also an appropriate medium for learning. Through traditional games, Kids can play with cheerful. After the game is over, they are unaware of the knowledge they get. Traditional games provide learning to children about the importance of maintaining the environment, respect others, to love to God. Traditional games are close to nature and contribute to improving intelligence natural child, also for the personal development of children. This game can be made alone so that it can train the creativity and responsibility of the child. 
The traditional game is a hereditary heritage. Traditional games are found by children. In contrast to children of modern times who know gadgets in children of ancient familiar traditional games that tend to be practical, simple and easy to play According to Danandjaja Traditional games are divided into two namely play games with games to compete. Traditional games are usually aimed at children who at this time are very happy to play. Games and children are inseparable. Almost all the time the lives of children are always in play condition. Naturally, a child who grows somewhere will play a traditional game that develops in place. Symptoms like this are still very often encountered in rural areas and rarely encountered in urban areas, which has been largely replaced by modern games. The traditional game basically has the fundamental activity as Brunvand puts it in Danandjaja as follows: Traditional gameplay is usually based on gestures such as running, jumping, or based on simple social activities, such as chase, concealment, and fighting; or based on basic mathematics or dexterity of the hands, such as counting, and throwing, the stone of a certain hole; or based on circumstances of chance, such as playing dice (Dananjaja, 1986). Traditional games are usually performed in teams or teams. But there are only done alone. Traditional games are always done for entertainment. Traditional games are usually performed by all children and are not looked at by gender. Children's games in the area can be used as an activity undertaken by children for the benefit of physical coaching and mental attitude in question

\section{Research Method}

This research includes descriptive qualitative research. This study explores the traditional game culture of Java and relate it to the learning of mathematics. Subjects in this study are children of Javanese who ever played "jiting-jitingan". Javanese tribes spread throughout most of the region. This study uses the subject of tribal children who live in Metro Lampung. From the information obtained further, the researchers connect with mathematics learning on the subject line and gradient.

\section{Finding and Disscussion}

\subsection{Traditional Game "Jiting-jitingan"}

The apprentice game "jiting-jitingan" is a simple game that uses the only tool in the form of sticks. this game does not distinguish between men and women because this game prefers peace of mind and does not give priority to physical so that both men and women have the same ability in playing this game. The tool used is very simple too that is only the ribs are cut into three types with different lengths. The first type of stick is one stick that has the longest size. This one is called headman, if the player can take the stick then it will get 15 points. Then, the second type of stick is one stick that has a medium size, this stick is called vice headman, if the player can take this stick then it will get 10 points. And the last type of stick that is some stick shortest size called citizens, if the player can take this stick then it will get 5 points. The player who earns the most points then he is the winner.

The number of participants of this game varies, ranging from 2 people or more. However, for this game to run well and not wait long, then this game is effectively played by $2-4$ people because this game is done alternately in sequence. The playground can be done on the ground 
or on the floor (depending on conditions). In addition to simple game equipment, the rules of the game and how to play it is quite simple and easy. The rules of the game there are only two that the player should not touch the other stick beside the stick that will be taken and the player should not replace another stick if the player feels the initial stick that will be taken quite difficult. While how to play as described below:

1) Games played at least by two people

2) The first player holds a collection of the stick that has 3 sizes and placed on the floor or table

3) Then, the player releases his grip so that the scattered sticks

4) Then the player picks up a scattering stick with a long stick with the tip at the right angle.

5) If the player managed to take the stick without moving the other stick then the player gets points. However, if the player while grabbing the stick is moving another stick then the game is finished and gentian with his opponent.

6) The game will keep running until the tray runs out. After all the stickers have been exhausted, each player will count the number of pitches he has collected. The player who gets the most points then he is the winner.

\subsection{Relationship between Game and Mathematics Concept}

At the secondary school level, there is a line material and gradient being taught. The material discussed is about the equation of the line, the position of two lines and the line gradient. Teaching abstract mathematics certainly creates problems for learners who have a low power of reason.

\subsubsection{Line Equation}

The line equation can be obtained by determining the two pairs of points through which the line passes. Traditional game "jiting-jitingan" can be used as media to teach the equation of the line. After the stick is propagated, the stick representing the position of a line is placed on the printed paper so that it can be seen as the coordinates of the base and the end of the line. the game of the "jiting-jitingan" is much more headed by the line elements so that the sticks also have the equation of the line with the help of the

rectangular coordinates of the scattered ribs that can be known. After created cartesian coordinates, it will get the value of point $\mathrm{x}$ and point value $\mathrm{y}$, after obtaining the value of $\mathrm{x}$ and $y$, the next step write the equation of the line that basically writing the equation of a straight line can be done in two ways:

$$
\mathrm{y}=\mathrm{mx}+\mathrm{c}
$$

with $\mathrm{m}$ and $\mathrm{c}$ being constants while $\mathrm{x}$ and $\mathrm{y}$ are variables.

$$
a x+b y+c=0
$$


with $\mathrm{a}, \mathrm{b}$ and $\mathrm{c}$ are constants while $\mathrm{x}$ and $\mathrm{y}$ are variable.

\subsubsection{Gradient Lines}

The gradient of a line is the value of the ratio between the change of ordinate and the change of abscissa from a point to a point located on the line. Each straight line must have a gradient and a gradient between one line and the other can be different depending on the ordinate and abscission of each line. The gradient is symbolized by the letter $m$. In the explanations he has discussed above, in the game of "jiting-jitingan" apprentices, there are many lines that are the stick itself and each line must have a gradient, so it can be concluded that the ribbons in the game of "jiting-jitingan" has a gradient on each stick. In search of the gradient the first thing that must be there is the point value of $x$ and $y$. in the discussion of the equation of the line has been described, to obtain the equation of the line then made cartesian coordinate aid. The general equation looks for the gradient $\mathrm{m}=\mathrm{y} / \mathrm{x}$

with $\mathrm{m}$ being the gradient, $\mathrm{y}$ is the component $\mathrm{y}$ and $\mathrm{x}$ is the component $\mathrm{x}$. if the equation of the line is $\mathrm{ax}+\mathrm{by}+\mathrm{c}=0$ then to find the gradient can be done in two ways that is by making a coordinate table and change the form $a x+b y+c=0$ into $y=m x+c$.

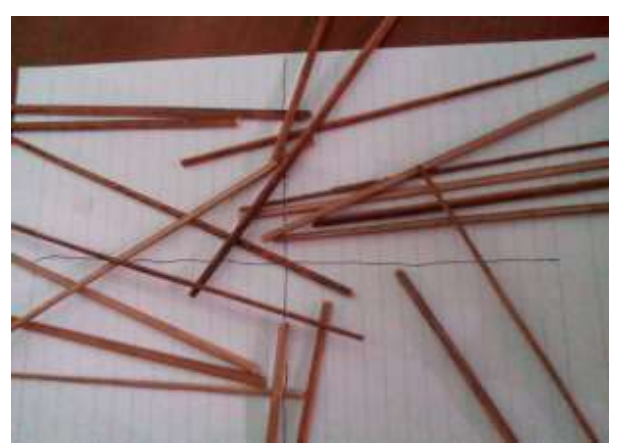

Figure 1. Sticks which represents gradient lines

\subsubsection{Position of Lines}

From the picture above it can be seen that in the game plenary lunar or milan-milan there are four possibilities about the position or position between two lines or two sticks are straight, namely:

\section{Two Lines Are Parallel}

As in a mil-milan game, if two lidi lie on a plane and will never meet or intersect if the stick is stretched to infinity, then the stick is called a stick mutually aligned. 


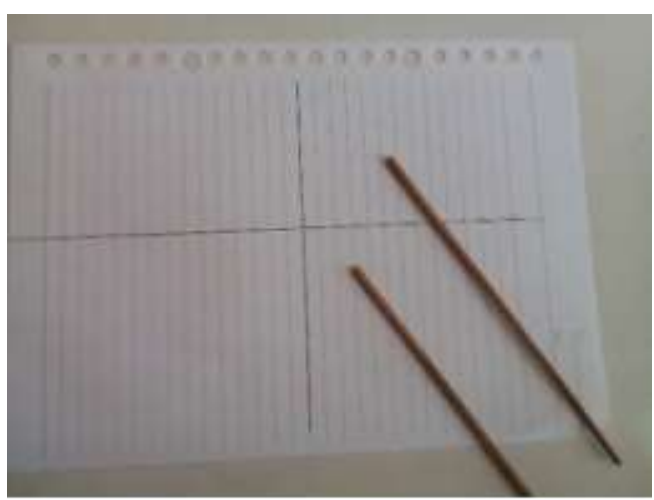

Figure 2. Sticks represents two lines are parallel

Thus, two or more lines are said to be parallel when the lines lie on a plane and will never meet or intersect if the line is extended infinitely. Both lines are parallel so that the second gradient of the line is the same or can write $\mathrm{mAB}=\mathrm{mFG}$.

\section{The Two Lines That Mutually Cut Upright Straight}

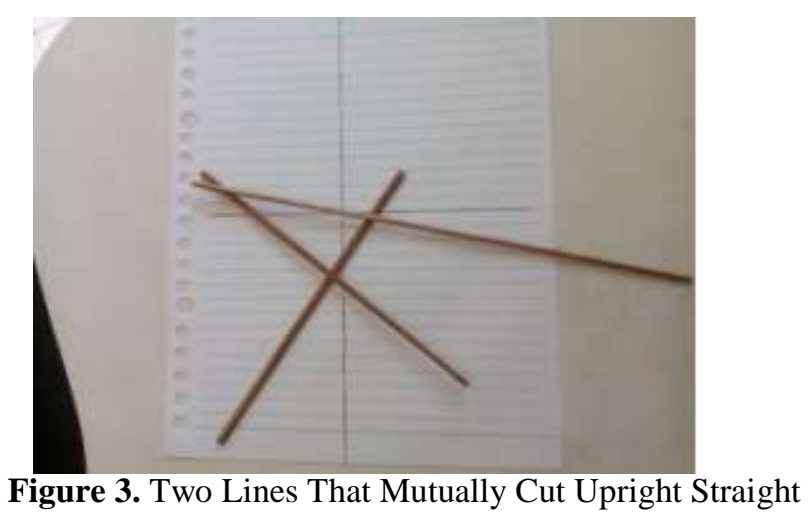

The intent of two intersecting lines perpendicular to each other is that if two lines or in the game use the intersection of each other when drawn the line until not until and at the point of cut from $90^{\circ}$ angles then the two lines are said two lines intersect each other perpendicularly. To find the value of the line gradient then use the equation $\mathrm{mAB} \times \mathrm{mFG}=-1$

\section{Two Intersecting Lines Aren't Perpendicular}

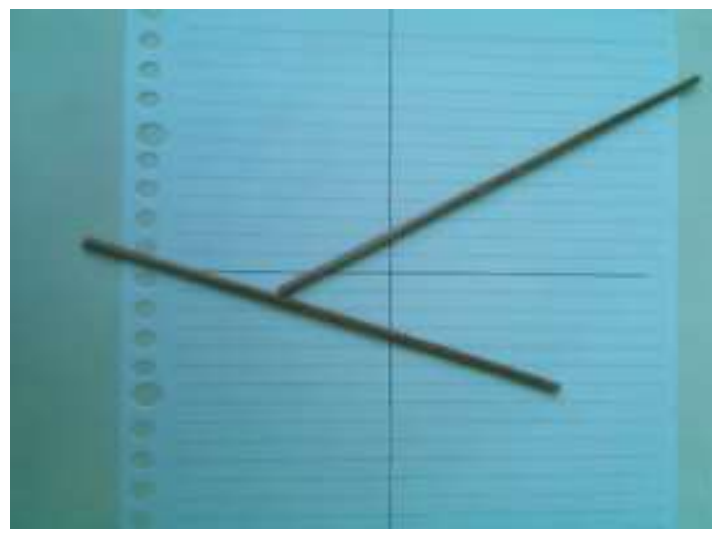


Figure 4. Two intersecting lines aren't perpendicular

Two intersecting lines but the angle produced at the cut point is not equal to $90^{\circ}$ then the two lines are said to be two intersecting lines but not perpendicular.

\subsection{Benefits Playing "Jiting-jitingan"}

In addition to being a learning medium for delivering line and gradient topics, there are other benefits gained from playing "jiting-jitingan". Benefits gained are instilling values of the child's character.

1) Can learn about the meaning of patience. In this game one of the keys to his victory is to be patient, if the player is impatient then he will quickly lose the game.

2) Train focus. In addition to patients, the focus is also needed in this game, when they want to take the stick players have to focus so that other stick does not move.

3) Learn to count. In this game, each stick has its own points and at the end of the game, each player will calculate the points he gets. Most points in the game are the winners.

4) Train interacts with others. This game is a type of game that should be played more than one person so that each player will do the interaction while understanding the opponent's play.

5) Can cultivate a sense of tolerance with others. In this game, each player is taught to tolerate inter-sesame because this game does not distinguish between men and women so it can be concluded in this game never distinguish between one individual with another individual.

6) The feeling of togetherness. In addition to fostering a sense of tolerance between individual lord, game apprentices can also generate a mutual feeling of each other.

7) Training accuracy. In this case, the players who have not got a turn to play will be very closely watching every stick that is taken by his friend. They are so meticulous that when the player shakes the other stick then simultaneously will say "mil".

\section{Conclusion}

The line equation can mathematics learning with ethnomathematics approach based on a traditional game is one form of innovative approach to learning. Integrating game and culture 
mathematics into activities that need to be done. Mathematical materials that can be taught through this game are addition, lines, and gradient. Ethnomatematics on traditional Javanese games can be utilized as a source learning in learning, increasing students' insight into whereabouts the mathematics that exist in one of the cultural elements they have, improves motivation in learning and facilitating students in linking concepts which is studied with realworld situations. For interested readers it can exploring further the existence of etnomatematics in other traditional games..

\section{References}

[1] S. Widyawati, M. Mardiyana, and G. Iswahyudi, "Eksperimentasi Model Pembelajaran Kooperatif Tipe Two Stay Two Stray (Tsts) Dan Numbered Heads Together (Nht) Ditinjau Dari Kecerdasan Majemuk Peserta Didik," J. Pembelajaran Mat., vol. 2, no. 9, 2014.

[2] E. F. Ningsih, "Proses berpikir mahasiswa dalam pemecahan masalah aplikasi integral ditinjau dari kecemasan belajar matematika (Math Anxiety)," J. Iqra' Kaji. Ilmu Pendidik., vol. 1, no. 2, pp. 191-217, 2016.

[3] I. Rachmawati, "Eksplorasi etnomatematika masyarakat Sidoarjo," MATHEdunesa, vol. 1 , no. $1,2012$.

[4] M. Rosa and D. Orey, "Ethnomathematics: the cultural aspects of mathematics," Rev. Latinoam. Etnomatemática Perspect. Sociocult. La Educ. Matemática, vol. 4, no. 2, pp. 32-54, 2011.

[5] K. R. Puspadewi, "Etnomatematika di Balik Kerajinan Anyaman Bali," J. Mat., vol. 4, no. 2, pp. 80-89, 2014.

[6] Y. Germain-McCarthy, Mathematics and multi-ethnic students: Exemplary practices. Routledge, 2017.

[7] R. H. Lowie, Culture \& ethnology. New York: DC McMurtrie, 1917.

[8] H. S. Asnawi, "Membongkar Patriarkhisme Islam sebagai Kearifan Budaya Lokal: Sebuah Kritik terhadap UU. No. 1 tahun 1974 tentang Perkawinan,” Esensia J. IlmuIlmu Ushuluddin, vol. 13, no. 2, pp. 223-240, 2012.

[9] B. Busro and H. Qodim, "Perubahan Budaya dalam Ritual Slametan Kelahiran di Cirebon, Indonesia,” J. Stud. Agama dan Masy., vol. 14, no. 2, p. 127, Sep. 2018.

[10] I. Inrevolzon, "Kebudayaan dan Peradaban," Tamaddun J. Kebud. dan Sastra Islam, vol. 13, no. 2, 2013.

[11] Koentjaraningrat, Kebudayaan, Mentalitas dan Pembangunan. Jakarta: Gramedia, 2000.

[12] C. Handika, "Kebudayaan Dalam Pandangan Hadis," Diroyah J. Ilmu Hadis, vol. 3, no. 2, pp. 61-72, 2019.

[13] D. Sumpena, "Islam dan budaya lokal: Kajian terhadap Interelasi Islam dan budaya Sunda," Ilmu Dakwah Acad. J. Homilet. Stud., vol. 6, no. 1, pp. 101-120, 2012.

[14] E. dona Martyn, "Permainan Tradisional Jawa Di Desa Sulusuban Kecamatan Seputih Agung Lampung Tengah," Universitas Lampung, 2016.

[15] A. S. Mukarom, "Pribumisasi Dalam Pandangan Abdurahman Wahid," Relig. J. Stud. Agama-Agama dan Lintas Budaya, vol. 2, no. 1, p. 63, Apr. 2018.

[16] J. Hasse, "Dinamika Hubungan Islam dan Agama Lokal di Indonesia: Pengalaman Towani Tolotang di Sulawesi Selatan," Wawasan J. Ilm. Agama dan Sos. Budaya, vol. 1, no. 2, pp. 179-186, Aug. 2016. 